\title{
A CIDADE ILUMINISTA NA AMAZÔNIA
}

Luís Heleno Montoril Del Castilo*

RESUMO:

Este artigo trata da transformação do espaço amazônico segundo a lógica do projeto iluminista ocorrida em fins do século $X I X$ e início do XX. Apresenta alguns trechos de textos oficiais e relatos de viagens que deixam patente a lógica dessa transformação.

PALAVRAS-CHAVE: cidade, Amazônia, iluminismo, relatos de viagens.

A cidade amazônica, notadamente Belém do Pará, é um espaço do projeto iluminista de fins do século XIX e início do XX. David Harvey (Harvey, 1993) define - lugar e o espaço como elementos distintos. No feudalismo, o primeiro estaria relacionado ao interior das organizações interpessoais legalmente estabelecidas. Deste modo, o lugar é o que é conhecido, delimitado. 0 lugar estabelece fronteiras que o levam ao isolamento em relação aos mundos exteriores a ele. Essa é a relativa segurança proporcionada pela manutenção do que é familiar aos que habitam o lugar. Quanto ao espaço, este seria exterior, estranho ao lugar conhecido. Daí o mistério, o mito e a imaginação terem sido as forças profusoras do espaço no feudalismo. Assim, o tempo do lugar era o do cotidiano que subsistia ao tempo exterior a ele, o tempo do eterno, o tempo do espaço.

À medida que o lugar se expande, o espaço se comprime. A compressão do espaço tem sua origem na Renascença. As viagens do descobrimento expandiram o lugar, no sentido mesmo de expandir a legalização político-social do lugar original em direção a outros territórios outrora desconhecidos. No processo expansionista, os descobridores da finitude do globo e da importância do saber geográfico. Descobriram também que a dominação do espaço era o pressuposto básico para o acúmulo de riquezas.

| * Doutor em Letras: Literatura, Histōria e Memória Cultural (Área de concentração: Literatura Comparada), 2004. 


\section{EMTESE}

Belo Horizonte, v. 9, p. I-28I, dez. 2005

Na transição do feudalismo à Renascença, lugar e espaço passam a se movimentar. Enquanto no feudalismo lugar e espaço estavam separados pelo que era familiar e estranho, na Renascença, o espaço passa a existir como território abrangente em que diversos lugares estão em relação. Isso não quer dizer que o espaço se tornou mais próximo, ele continua distante daquele que o observa. Talvez poder-se-ia dizer que o lugar é o território do vivido e o espaço sobrevive da representação e imagem projetadas. 0 espaço é visto em perspectiva, não é vivido.

Geometrização e sistematização do espaço definem o espírito renascentista, qual seja o de organização com o fim de harmonizar o mundo segundo o universo organizado de Deus. 0 perspectivismo originado daí parece anteceder e prenunciar o advento iluminista de controle e organização do espaço sob o predomínio do visual. Neste sentido, tem-se de um lado a ciência da óptica e de outro a mitologia e a religião. Há nesta visualização do mundo o "olho que vê do indivíduo". Individualismo e perspectivismo serão as bases do vindouro cartesianismo racionalista do projeto iluminista.

0 domínio da natureza através da organização racional do espaço e do tempo faz o homem ter autoconsciência de seu poder demiúrgico. Distancia-se do pensamento mágico e mítico potencializando sua vontade de saber. 0 indivíduo que emerge do espírito renascentista vai culminar no princípio iluminista de dominação do futuro "por meio de poderes de previsão científica, da engenharia social e do planejamento racional e da institucionalização de sistemas racionais de regulação e controle social." (Harvey, 1993: 227)

Horkheimer e Adorno (Horkheimer e Adorno, 1991) consideram fundamento do iluminismo a liberdade. Esta surge no momento exato em que o homem perde o medo da natureza e passa a ter consciência de si. Logo no primeiro parágrafo do texto "Conceito de iluminismo", os autores recorrem às palavras de Francis Bacon de que "a superioridade do homem reside no saber" (Horkheimer e Adorno, 1991: 3). Saber, nesse contexto, relaciona-se à múltipla possibilidade de explorar a natureza para o benefício da economia burguesa. Esse saber não é o divino e absoluto do rei mas humano e relativo ao indivíduo que o detém segundo a técnica, o método, a exploração do trabalho do outro e o capital. Saber é poder no sentido mesmo de que "o que importa é a operation" (Horkheimer e Adorno, 1991: 4). 
Para o iluminismo, ter consciência de si é ter consciência de que não é possível ter consciência de si. Voltar-se sobre si é parar a máquina. Desse modo, o iluminismo caminha em busca da ciência moderna, em que os homens se despojam do sentido absoluto, essencial e verdadeiro. 0 valor deixa de ser os universais simbólicos do mito e da superstição para dar lugar à fórmula, à regra, à probabilidade, ao cálculo e à utilidade.

Para Horkheimer e Adorno, a versão do iluminismo, segundo a qual o mundo se dá a conhecer racionalmente, é totalitária. Ele reduz o mito a um único sujeito. 0 que foge ao controle da razão e à unidade do sistema iluminista não é reconhecido como ser e acontecer. Paradoxalmente, "a multiplicidade das figuras é reduzida à posição e à ordenação; a história ao fato; as coisas à matéria" (Horkheimer e Adorno, 1991: 4). A esse respeito, o texto de Horkheimer e Adorno esclarece que a busca pela uniformização empreendida pelo iluminismo teve na lógica formal a sua principal escola: "o número se tornou o cânon do iluminismo" (Horkheimer e Adorno, 1991: 6) e a unidade o valor apriorístico para a ordenação do mundo. Na equação do sistema matemático iluminista em direção à unidade, os restos, para dizer aritmeticamente, são esquecidos. Eles equivaleriam ao mito. A natureza, no plano mágico, se apresentava como entidade invisivel, que continha o em-si, ou o ser que constituía sua identidade. Esse em-si passa a ser dominado pelo homem de ciência. 0 em-si passa a ter o sentido de para-ele no iluminismo. 0 que no plano mágico era "controlado" através de similitudes entre o feiticeiro e os fenômenos naturais, no iluminismo o controle se dá através da lógica discursiva e da funcionalidade. A natureza não é, mas tem. "As múltiplas afinidades entre entes são reprimidas por uma única relação entre o sujeito doador de sentido e o objeto sem sentido, entre a significação racional e o suporte causal da significação" (Horkheimer e Adorno, 1991: 8). Os autores consideram que essa radical desmitologização do mundo é uma mitologização, não do mundo, mas do iluminismo mesmo. A objetualização da natureza em leis científicas é o princípio mesmo da repetição que, pretensamente, teriam libertado o homem da imaginação mítica, são elementos de um novo círculo que o limita. Nesse círculo há uma eterna mediação universal, as qualidades das coisas se acabam 


\section{EM TESE}

Belo Horizonte, v. 9, p. I-28I, dez. 2005

no pensamento e os homens são conformados ao real. Enquanto na imaginação do homem préiluminista o mito identificava o inanimado com o animado, no pensamento do homem iluminista o logus identifica o animado com o inanimado. "0 iluminismo é a angústia mítica que se tornou radical" (Horkheimer e Adorno, 1991: 12).

A igualdade e a unidade pretendidas pelo projeto iluminista devem ser atingidas, nem que para isso seja necessária a coação social. Há sob a existência luminosa do referido projeto um fundamento senhorial. A relação de distanciamento entre homem e natureza é também outra forma de estabelecer a relação homem civilizado/homem natural ou selvagem; entre senhor/servos. No caso do iluminismo, é senhor aquele que detém o saber e a técnica para o funcionamento do mundo e para a dominação da realidade. 0 senhor é o homem livre, ou o homem livre é o senhor. Neste sentido, a igualdade é um fetiche. "A venda sobre os olhos da "Justitia" não significa somente a proibição de intervir no direito; ela diz ainda que o direito não provém da liberdade" (Horkheimer e Adorno, 1991: 13).

Com esta pré-visão do mundo, o espaço iluminista surgiria desde já preestabelecido. De nenhum modo haveria necessidade de recorrer-se às origens, às raízes, aos antepassados, para o agenciamento do espaço urbano. Não há lugar no iluminismo.

Sob esse ponto de vista, a área da grande floresta amazônica se apresentou - e ainda se apresenta - como o grande desafio de dominação da civilização da técnica sobre a natureza. As duas metrópoles da Amazônia brasileira, Belém e Manaus, representam esse espaço de transição e dialética entre natureza e civilização. Representam também o clarão iluminista no meio da selva que teve seu início no chamado Ciclo da Borracha. Essas cidades, sob a ótica e a lógica do iluminismo, são paraísos artificiais onde todos são livres e iguais.

As bases para a modernização urbana da cidade iluminista e de seu desenvolvimento são sua evolução tecnológica e sua evolução da organização social. 0 progresso tecnológico surge como o grande propulsor para a expansão da cidade, no entanto, isto se torna viável a partir de uma organização social que assim o permita.

Os naturalistas, que viajaram pela região amazônica do século XIX, deixaram transparecer em suas crônicas de viagens a mudança considerável 
daquele espaço. É de 1859 uma dessas impressões. Henry Walter Bates, sobre Belém, observou que a aldeia cheia de mato vista por ele em 1848, dera lugar ao calçamento limpo, o que era constituído de caminhos alagadiços outrora, dera lugar ao terreno planificado e racionalmente dividido. Sobre os alagados, importa deixar bem claro que Belém foi construída sobre um território recortado de igarapés e furos de rio, muitos deles foram aterrados, ou tiveram que ser contornados por docas de concretos demonstrando assim o pensamento racionalista de ordenação do espaço natural.

Achei o Pará muito modificado e melhorado (...) as ruas antes sem calçamento ou salpicadas de pedras soltas e areia, estavam agora pavimentadas de concreto (...) as praças alagadiças tinham sido drenadas, limpas de plantas daninhas e plantadas com filas de amendoeiras e casuarinas, de modo que eram atualmente grande ornamento da cidade em vez de uma chaga, como antes. (Bates, 1979: 127)

Considerando a impressão de Bates sobre a praça como chaga, poder-se-ia dizer que a civilização é o modo de pensá-la, com toda a ambigüidade que está contida nesta expressão.

Em 1875, o governador Pedro Vecente de Azevedo escreveu:

Ocupando uma extensa área, possuindo notáveis edifícios públicos e alguns doze jornais, sendo nada menos do que cinco diários, seu lindo porto enfeitado de navios procedentes do Sul do Império, Estados Unidos, Europa e, sobretudo, dos que navegam constantemente para diversas linhas do Amazonas e Tocantins, apresenta aos olhos do estrangeiro uma animação e progresso que não estão em harmonia com essa decadência das cidades do interior. (Penteado, 1968: 133).

Tanto em Bates, naturalista estrangeiro, como em Azevedo, que governa para estrangeiros, ou para inglês ver, a cidade de Belém é um ornamento. Eles representam bem o espírito iluminista em que o sujeito é doador de sentido. 0 ornamento define a primazia do estético sobre o utilitário. A cidade em meio a selva deve ser a representação de um objeto de desejo aos olhos do estrangeiro. A estranheza da floresta, dos rios, dos alagados e das chagas, deve ser transformada em um espaço familiar ao estrangeiro. Neste sentido, a floresta e os alagados são a grande muralha para a construção dessa cidade ideal.

A cidade nas selvas sofre da condição de querer estar acessível ao estrangeiro de um lado e de ter a muralha natural como barreira por outro. Se por um lado ela se abre através da epígrafe de Victor Hugo, se dá como ornamento 


\section{EM TESE}

Belo Horizonte, v. 9, p. I-28I, dez. 2005

em Bates e como possibilidade de progresso em Azevedo; por outro as florestas e rios deverão ser transpostos, bem como transportados, para que haja a possibilidade de estender os limites para além da cidade.

A paisagem urbana da capital paraense irá se transformar na medida que o sucesso da borracha permitirá. É do período de 1860-1870 a construção do Mercado Municipal junto ao Ver-o-peso, a instalação da freguesia de Nazaré, a inauguração da iluminação a gás carbônico (que iria perdurar até 1896), a fundação do Hospital D. Luiz e o Grêmio Literário.

Enquanto a exportação crescente da borracha ia sustentando a carência de outros produtos via importação, Belém pôde gozar deste superávit. Era uma sociedade de números. A civilização se apresenta, já na década de setenta, nas ruas da cidade, em paralelepípedos de granito importados de Portugal, no edifício do Arquivo e Biblioteca Pública, no Consulado da Bolívia, na construção definitiva do Hospital D. Luiz, na inauguração dos serviços telegráficos através de cabos submarinos e na pedra fundadora da civilização moderna na cidade, o Teatro da Paz. Neste espaço, de fevereiro a dezembro de 1878, nada menos do que 126 espetáculos foram apresentados.

A cidade se mostra em números, estatisticamente mensurada, atestado este de uma mecânica moderna de resultados visando o progresso. 0s documentos estatísticos são um dado importante porque atestam a presença de especializações e a partidarização na organização social. Assim parece claro a modernização não só do espaço, mas dos meios de organização e de distribuição de tarefas, trabalhos e deveres.

0 mercado é um dos melhores do Império e sempre mais ou menos abundante de frutas, hortaliças, legumes, carnes, aves, peixes e outros gêneros. Os balcões de seus açougues são de mármore e as ruas do seu interior são calçadas a paralelepípedos de granito, tendo no centro um elegante chafariz (...) era iluminada por 1564 lampeões de gás, possuía uma rede telefônica com pouco menos de 200 quilômetros e 120 aparelhos (...) 55.000 metros e 1873 registros (esgoto e água potável) em edifícios particulares e públicos (...) 6551 prédios, dos quais um grande número de 2 pavimentos, diversos de 3 , alguns de quatro e a maior parte de um só. (...) não faltavam seis jornais diários e cinco semanários, duas companhias de bondes e um movimentado porto (...) cinco bancos (três com sede em Belém e dois ingleses), quatro companhias seguradoras, 387 lojas (101 de fazendas), 103 escritórios de comissões, doze hotéis, treze agentes de leilão, quarenta e um advogados, cinqüenta e 
dois médicos, quarenta e três fábricas (12 de fogos de artifícios, quatro de malas, dez de licor, uma de chapéu de sol, uma de perfumaria, uma de carro de luxo, quatro de caixas de borracha, quatro de cal, uma de chocolate, uma de cera, uma de instrumentos de corda e de fole, uma de figuras de gesso, uma de figuras de cera, uma de gasosas. (Penteado, 1968: 133).

Uma cidade tem densidade populacional considerável. Nela há uma diversidade de especialidades não agrícolas exercidas pela elite culta. A tradição oral na cidade dá lugar à tradição escrita. A organização social se torna mais complexa acompanhando a complexidade intelectual. É a palavra escrita e o número que dão o contorno da estrutura social.

No ultrapasse da metade do século XIX, Belém sofre a verdadeira transformação que a tornará, na década de oitenta daquele século, o palco das "ilusões perdidas" de muitos e realizações capitalistas de outros.

Marc Alfred vai ratificar esta cidade por volta de 1899:

0 simples aspecto do porto dá ao recém-chegado a impressão do grande desenvolvimento desta zona comercial. 0 vai-e-vem contínuo dos vapores, das canoas, dos barcos e das inumeráveis embarcações, singrando o cais em todas as direções, o movimento do trabalho sobre as anotações, testemunham que se penetra em um centro de atividade em pleno desenvolvimento. (Penteado, 1968: 133)

A Belém de fins do século XIX e início do XX é um espaço e não um lugar. Primeiro: no sentido de que não teve raízes culturais fundadoras, mas sim foi a materialização da utopia iluminista européia que reprimiu o em-si mágico da culturas indígenas e caboclas, outorgando poderes aos naturalistas do século XIX com o objetivo de transpor a muralha natural; segundo: no sentido de que estará sempre distanciada da realidade amazônica que a margeia, para os caboclos e índios, ela carrega o eterno mistério do que Thes é estranho; terceiro: no sentido de que, na concepção iluminista, ela representa a possibilidade de liberdade do homem que sabe a técnica de dominação da natureza, o método de como proceder tal dominação, que é livre porque subjuga a natureza e o outro para ele num processo de objetualização que o levará ao acúmulo do capital. 


\section{EMTESE}

Belo Horizonte, v. 9, p. I-28I, dez. 2005

ABSTRACT :

This article treatments for the amazon space in conformity to the project illuminist occurred in the end XIX century and beginning $X X$ century. It presents same official texts and travel reports that show the logic of this transformation.

KEY WORDS: city, Amazônia, illuminism, travel reports.

REFERÊNCIAS BIBLIOGRÁFICAS

HARVEY, David. A Condição pós-moderna. São Paulo: Loyola, 1993.

HORKHEIMER, Max; ADORNO, Theodor. Conceito de iluminismo. In: Textos escolhidos. Trad. Zeljko, et.al. 5. ed. São Paulo: Nova Cultural, 1991. (Os Pensadores, 16).

BATES, Henry Walter. Um naturalista no rio amazonas. Belo Horizonte: Itatiaia; São Paulo: EDUSP, 1979. p.127. PENTEADO, Antônio Rocha. Belém, estudo da geografia urbana. V. 1, cap. II. Belém: Universidade Federal do Pará, 1968. 